\title{
IAMJ
}

INTERNATIONAL

AYURVEDIC

MEDICAL JOURNAL

\section{TO STUDY THE EFFICACY OF AYURVEDIC TREATMENT IN COVID-19/SARS-COV-2}

\author{
Ravindrakumar Mane', Ram Lade ${ }^{2}$ \\ ${ }^{1}$ MD Rasashastra, ${ }^{2} \mathrm{MD}$ Shalyayantra, \\ Ayurved Chikitsak, Vivekanad Multispeciality Hospital and Research Centre, Bamnoli (Kupwad), Tahasil- Miraj, \\ Dist. Sangli, Maharashtra. 416436, India
}

Corresponding Author: ravindrapmane@gmail.com

https://doi.org/10.46607/iamj05p5022021

(Published online: January 2021)

Open Access

(C) International Ayurvedic Medical Journal, India 2020

Article Received: 06/01/2021 - Peer Reviewed: 12/01/2021 - Accepted for Publication: 15/01/2021

Check for updates

\begin{abstract}
To overcome COVID-19 infection there is no any precise \& effective management plan so far available in contemporary Medicine. Therefore, an attempt of administering Ayurvedic medicines to alleviate signs \& symptoms of Novel Corona virus is taken into consideration. A clinical trial was performed in hospital with the combination of pure herbo-mineral Ayurvedic medicines named as 'Shwashara' along with modern medicines over 93 infected indoor subjects. In total sample size, $76.34 \%$ subjects had co-morbidities, after treatment it is been observed that, $29.58 \%$ of these subjects did not need oxygen support. $52.69 \%$ of subjects had HRCT score more than half. $58.06 \%$ were recovered within 7 Days. Out of 471 patients, who received only modern medicines had death rate of $10.02 \%$ and the Subjects treated with both systems of medicines have recorded $2.15 \%$ death. The 'Shwashara' medicine decreases symptoms of pneumonia \& COVID-19, strengthen lungs and reduces death rate significantly.
\end{abstract}

Keywords: Covid-19, SARS-CoV-2, Ayurvedic treatment, Panchabhautik Chikitsa, Shwashara

\section{INTRODUCTION}

Covid-19 pandemic condition is highly infectious viral infection spreading so fast all over the world. In
India, we have faced and controlled many pandemics very nicely. But this pandemic condition is totally new 
for us. Earlier study ${ }^{1}$ confirms that, people who have underlying conditions such as cardiovascular disease, diabetes, kidney disease, high blood pressure or cancer are at greater risk of dying due to covid-19. The overall case fertility rate of people with co-morbidities stood at $17.9 \%$ and for those without co-morbidities, it was $1.2 \%$. In this infection, Initial fever, cough, generalized weakness, sore throat and Breathlessness are the common symptoms. Cytokine storm is the reactionary phase can develop in the body in 5-6 days to 12-14 days after infection. Pneumonia develops in Cytokine storm and patient may need oxygen support during treatment. So far there is no any specific treatment in modern system of medicine. In Ayurveda texts, Sansargajanya Vyadhi (Infectious Diseases) and Janpadodhwansa Vadhi ${ }^{2}$ (Pandemic) are explained deeply. By considering basic things explained in texts, we have tried to do clinical study by treating the patients of Covid-19 infection. We have used the combination of medicines for treatment and named it as 'Shwashara'. The name has been given on the basis of classical texts as, 'Shwasa' means breathlessness and 'Hara' means to decrease or to reduce or to remove i.e. breathlessness reducer.

\section{Aim and Objectives -}

- To study efficacy of 'Shwashara' to decrease the death rate in Covid-19 infection.
- To study action of 'Shwashara' in Covid-19 infection.

\section{Material and Methods -}

The study has been done in Vivekanand Hospital and Research Centre, Bamnoli, Sangli, Maharashtra, India. The Subjects who fulfilled the criteria for the selection were selected.

\section{Inclusive Criteria:}

- Subjects having Symptoms of Covid-19 Infection with Positive PCR or Antigen Test.

- Subjects who have co-morbidities like Diabetes Mellitus, Hypertension, Chronic cardiac diseases, Asthma.

- Subjects having contact history with asymptomatic, symptomatic, direct and high risk confirmed case.

- Old age subjects.

- Subjects who require oxygen support or not.

\section{Exclusive Criteria:}

- Subjects not having any symptoms related to Covid-19 infection.

\section{Drug Study:}

In this clinical study subjects were given a combination of Tribhuvankirti Rasa ${ }^{3}$, Tankanmarita Abhraka ${ }^{4}$, Kalingakadi, Patoladi Guggulu ${ }^{6}$, Chaturthaka ${ }^{7}$ and $\mathrm{Haralu}^{8}$ in powder form and Nagaradi Kalpa in liquid form. This combination has been given the name 'Shwashara'.

Table 1: Each $100 \mathrm{mg}$ of Tribhuvankirti Rasa contains.

\begin{tabular}{|l|l|l|l|}
\hline S.No. & Dravya & Proportion & Form \\
\hline 1 & Shuddha Hingula (Cinnebar) & $15 \mathrm{mg}$ & Churna \\
\hline 2 & Shuddha Bachanaga (Aconitum ferox) & $15 \mathrm{mg}$ & \\
\hline 3 & Shunthi (Zingibar officinale) & $15 \mathrm{mg}$ & \\
\hline 4 & Shwet Maricha (Piper nigrum) & $15 \mathrm{mg}$ & \\
\hline 5 & Pippali (Piper longum) & $15 \mathrm{mg}$ & \\
\hline 6 & Tankanlahi (Borax) & $15 \mathrm{mg}$ & \\
\hline 7 & Pimpalmula (Piper longum radix) & $15 \mathrm{mg}$ & \\
\hline
\end{tabular}

Table 2: Each 100mg of Kalingakadi contains.

\begin{tabular}{|l|l|l|l|}
\hline S.No. & Dravya & Proportion & Form \\
\hline 1 & Indrayava (Holarrhena antidysenterica) & $33.3 \mathrm{mg}$ & Churna \\
\hline 2 & Patolpatra (Trichosanthes dioica) & $33.3 \mathrm{mg}$ & \\
\hline 3 & Kutaki (Picrorhiza kurroa) & $33.3 \mathrm{mg}$ & \\
\hline
\end{tabular}


Table 3: Each 100mg of Patoladi Guggulu contains.

\begin{tabular}{|l|l|l|l|}
\hline S.No. & Dravya & Proportion & Form \\
\hline 1 & Patola (Trichosanthes dioica) & $16 \mathrm{mg}$ & Churna \\
\hline 2 & Sariva (Hemidesmus indicus) & $16 \mathrm{mg}$ & \\
\hline 3 & Musta (Cyperus scariosus) & $16 \mathrm{mg}$ & \\
\hline 4 & Patha (Cissampelos pareira) & $16 \mathrm{mg}$ & \\
\hline 5 & Katuki (Picrorhiza kurroa) & $16 \mathrm{mg}$ & \\
\hline 6 & Shuddha Guggulu (Commifora mukul) & $16 \mathrm{mg}$ & \\
\hline
\end{tabular}

Table 4: Each 100mg of Chaturthaka contains.

\begin{tabular}{|l|l|l|l|}
\hline S. No. & Dravya & Proportion & Form \\
\hline 1 & Shunthi (Zingibar officinale) & $30 \mathrm{mg}$ & Churna \\
\hline 2 & Guduchi (Tinospora cordifolia) & $7.5 \mathrm{mg}$ & \\
\hline 3 & Kirattikta (Swertia chirayita) & $30 \mathrm{mg}$ & \\
\hline 4 & Shwtchandana (Santalum album) & $30 \mathrm{mg}$ & \\
\hline
\end{tabular}

Table 5: Each $10 \mathrm{ml}$ of Nagaradi Kalpa contains.

\begin{tabular}{|l|l|l|l|}
\hline S.No. & Dravya & Form & Quantity \\
\hline 1 & Shunthi (Zinziber officinale) & Decoction & $0.625 \mathrm{gm}$ \\
\hline 2 & Guduchi (Tinospora cordifolia) & Decoction & $0.625 \mathrm{gm}$ \\
\hline 3 & Pushkarmula (Inula racemosa) & Decoction & $0.625 \mathrm{gm}$ \\
\hline 4 & Kantakari (Solanum xanthocarpum) & Decoction & $0.625 \mathrm{gm}$ \\
\hline 5 & Sugar & As it is & $8 \mathrm{gm}$ \\
\hline 6 & Dhataki (Woodfordia fruticosa) & As it is & $0.8 \mathrm{gm}$ \\
\hline
\end{tabular}

Study Design: In this clinical study total 93 subjects were undertaken. Study was initiated after taking written consent voluntarily and 'Shwashara' medicines were given along with modern medicines for 14 days. From these medicines, Combination of powder form of Tribhuvankirti Rasa, Tankanmarit Abhraka, Kalingakadi, Patoladi Guggulu, Chaturthaka was given to the Subjects at 6 am i.e. Anannakala (empty stomach) and Vyana \& Udana kala (After both meals) with warm water. Haralu was given at 10 am and $6 \mathrm{pm}$ And Nagaradi Kalpa at 6 am i.e. Anannakala and Vyana \& Udana kala (After both meals). Study drug preparation was done in home kitchen pharmacy of
SaiShree Ayurved Clinic, Sangli and used for the subjects admitted in Vivekanand Hospital \& Research Centre.

Observations and Results: In this study, 93 subjects were studied and completed clinical trial successfully. In 'Shwashara' combination TID dose of $100 \mathrm{mg}$ of Tribhuvankirti Rasa, Tankanmarita Abhraka, Kalingakadi, Patoladi Guggulu and Chaturthaka each was given at 6 am and after both meals with 30 to $40 \mathrm{ml}$ of warm water. And $10 \mathrm{ml}$ of Nagaradi Kalpa was given with combination. And BD dose of $100 \mathrm{mg}$ of Haralu was given at $10 \mathrm{am} \& 6 \mathrm{pm}$ with 10 to $15 \mathrm{ml}$ of regular water. (Table No.6)

Table 6: contents of 'Shwashara'

\begin{tabular}{|c|c|c|c|c|}
\hline S.No. & Kalpa & Form & Quantity & Dose and Anupana \\
\hline 1 & Tribhuvankirti Rasa & Powder & $100 \mathrm{mg}$ & \multirow{4}{*}{$\begin{array}{l}\text { Combination of } 100 \mathrm{mg} \text { each TID - } \\
\text { at } 6 \text { am and after both meals } \\
\text { with } 30 \text { to } 40 \mathrm{ml} \text { of warm water }\end{array}$} \\
\hline 2 & Tankanmarita Abhraka & Powder & $100 \mathrm{mg}$ & \\
\hline 3 & Kalingakadi & Powder & $100 \mathrm{mg}$ & \\
\hline 5 & Chaturthaka & Powder & $100 \mathrm{mg}$ & \\
\hline 6 & Haralu (Celosia argentea) & Powder & $100 \mathrm{mg}$ & $100 \mathrm{mg} \mathrm{BD}$ - at $10 \mathrm{am} \& 6 \mathrm{pm}$; With 10 to $15 \mathrm{ml}$ of regular water. \\
\hline
\end{tabular}


Among 93 subjects 85 i.e. $91.39 \%$ had history of $J w a$ ra (Fever); 89 i.e. $95.70 \%$ had history of Agnimandya (Loss of appetite); 90 i.e. $96.77 \%$ had Kaasa (Cough); 83 i.e. $89.25 \%$ had Shwasa (Breathlessness); 82 i.e. $88.17 \%$ had Daurbalya (Generalized Weakness); 53 i.e. $59.55 \%$ had Gala Shula (Sore throat); 3 i.e.3.3\% had Cchardi / Hrullasa (Vomiting / Nausea) and 2 i.e. 2.2\% had Agnimandya (Loss of appetite). (Table No. $7)$.

Table 7: Distribution according to Symptoms:

\begin{tabular}{|l|l|l|l|}
\hline S.No. & Symptoms & No. of subjects & Percentage \\
\hline 1 & History of Jwara (Fever) & 85 & $91.39 \%$ \\
\hline 2 & History of Agnimandya (Loss of appetite) & 89 & $95.70 \%$ \\
\hline 3 & Kaasa (Cough) & 90 & $96.77 \%$ \\
\hline 4 & Shwasa (Breathlessness) & 83 & $89.25 \%$ \\
\hline 5 & Daurbalya (Generalized Weakness) & 82 & $88.17 \%$ \\
\hline 6 & Gala Shula (Sore throat) & 53 & $59.55 \%$ \\
\hline 7 & Cchardi / Hrullasa (Vomiting / Nausea) & 3 & $3.3 \%$ \\
\hline 8 & Agnimandya (Loss of appetite) & 2 & $2.2 \%$ \\
\hline
\end{tabular}

All subjects had age more than 25 years. 12 i.e. $12.90 \%$ had age below 40 years; 44 i.e. $47.31 \%$ had age between 41 to 60 years and 37 i.e. $39.78 \%$ had

age equal to or more than 61 years. Among 93 Subjects 63 i.e. $67.74 \%$ were male and 30 i.e. 32.26 were female (Table No. 8).

Table 8: Distribution according to Age and Gender:

\begin{tabular}{|l|l|l|l|}
\hline S.No. & Age / Gender & No. of subjects & Percentage \\
\hline 1 & Below 40 years & 12 & $12.90 \%$ \\
\hline 2 & 41 to 60 years & 44 & $47.31 \%$ \\
\hline 3 & Above 61 years & 37 & $39.38 \%$ \\
\hline 4 & Male & 63 & $67.74 \%$ \\
\hline 5 & Female & 30 & $32.26 \%$ \\
\hline
\end{tabular}

71 i.e. $76.34 \%$ subjects had co-morbidities. Among these, 26 i.e. $36.61 \%$ had Diabetes Mellitus (DM); 18 i.e. $25.35 \%$ had Hypertension (HTN); 22 i.e. $30.99 \%$ had both DM and HTN; 5 i.e. 7.04\% had other co- morbidities like Parkinson's disease, Asthma, Angioplasty etc. And in total, 22 i.e. $23.66 \%$ subjects had no co-morbidity (Table No. 9).

Table 9: Distribution of subjects according to co-morbidities:

\begin{tabular}{|l|l|l|l|}
\hline S.No. & Co-morbidities & No. of subjects & Percentage \\
\hline 1 & Diabetes Mellitus (DM) & 26 & $36.61 \%$ \\
\hline 2 & Hypertension (HTN) & 18 & $25.35 \%$ \\
\hline 3 & DM and HTN & 22 & $30.99 \%$ \\
\hline 4 & Other & 5 & $7.04 \%$ \\
\hline 5 & No any & 22 & $23.66 \%$ \\
\hline
\end{tabular}

$58.26 \%$ i.e. 54 subjects were treated for 0 to 7 days.

$9.67 \%$ i.e. 9 were treated for equal to or more than 11 $32.25 \%$ i.e. 30 were treated for 8 to 10 days and days (Table No. 10).

Table 10: Distribution of Subjects according to treatment duration.

\begin{tabular}{|l|l|l|l|}
\hline S.No. & Treatment Duration in days & No. of subjects & Percentage \\
\hline 1 & 0 to 7 & 54 & $58.26 \%$ \\
\hline 2 & 8 to 10 & 30 & $32.25 \%$ \\
\hline 3 & 11 and above & 9 & $9.67 \%$ \\
\hline
\end{tabular}


Medicines were started to $40.86 \%$ i.e. 38 subjects when they were on Oxygen support of equal to or more than 6 lpm (liter per minute). Medicines were started to 31.18\% i.e. 29 subjects when they were on Oxygen support of 0$5 \mathrm{lpm}$. Medicines were started to $27.96 \%$ i.e. 26 subjects when they were not on Oxygen support (Table No. 11).

Table 11: Distribution according to Oxygen requirement in lpm (liter per minute) when started treatment.

\begin{tabular}{|l|l|l|l|}
\hline S.No. & Oxygen Requirement & No. of subjects & Percentage \\
\hline 1 & Equal to or more than $6 \mathrm{lpm}$ & 38 & $40.86 \%$ \\
\hline 2 & Up to 5 lpm & 29 & $31.18 \%$ \\
\hline 3 & No any & 26 & $27.96 \%$ \\
\hline
\end{tabular}

Among these 93 subjects 67 i.e. $72.04 \%$ had needed oxygen support during treatment. Out of these $25.37 \%$ i.e. 17 had needed oxygen support for 1 to 3 days; $50.74 \%$ i.e. 34 had needed oxygen support for 4 to 7 days; $16.41 \%$ i.e. 11 had needed oxygen support for 7 to 10 days; $7.46 \%$ i.e. 5 had needed oxygen support for more than 10 days. $27.96 \%$ i.e. 26 subjects did not need oxygen support during treatment. (Tablet No. 12).

Table 12: Distribution according to number of days needed oxygen support during treatment.

\begin{tabular}{|l|l|l|l|l|}
\hline S.No. & Oxygen level when started treatment & No. of subjects & Total & Percentage \\
\hline 1 & 1 to 3 & 17 & 67 & $25.37 \%$ \\
\hline 2 & 4 to 7 & 34 & & $50.74 \%$ \\
\hline 3 & 7 to 10 & 11 & & $16.41 \%$ \\
\hline 4 & 11 and more & 5 & 26 & $7.46 \%$ \\
\hline 5 & No any & 26 & & $27.96 \%$ \\
\hline
\end{tabular}

Out of 71 co-morbidities 21 i.e. $29.58 \%$ did not need oxygen support during treatment.

\section{Graph 1}

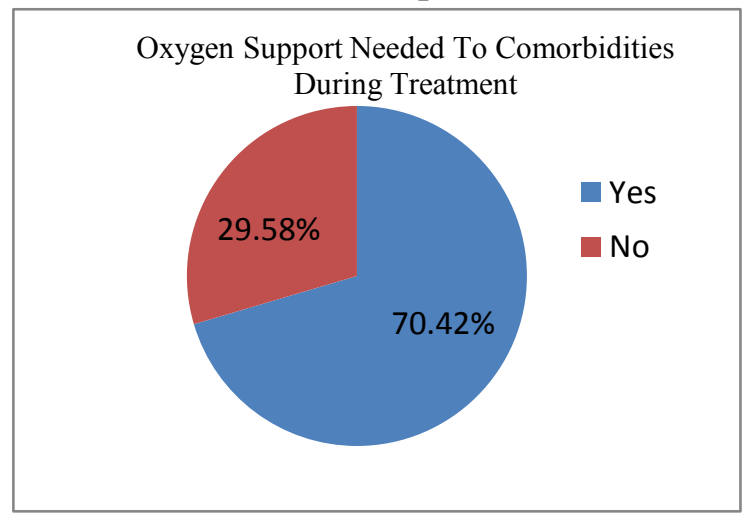

HRCT investigation had been done by 68 i.e. $73.12 \%$ subjects. Out of these, 49 i.e. $72.05 \%$ had score above $50 \%$ and out of these, 13 i.e. $26.53 \%$ did not require oxygen support during treatment. And in total, 19 i.e. $27.94 \%$ had score below 50\% (Tablet No. 12). Out of 93 subjects 2 i.e. $2.15 \%$ death has been recorded. 


\section{Graph 02}

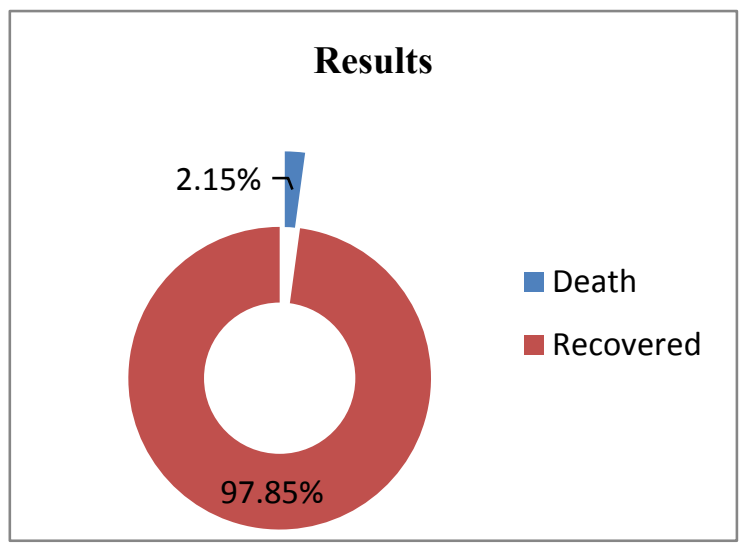

Statistical Analysis: Our objective is to prove the death rate of Ayurvedic treatment is $2.15 \%$ compared to total hospital death rate of $10.02 \%$. Therefore, we setup null hypothesis as $\mathrm{H}_{0}: \mathrm{P}=10.02 \%$ against alternative hypothesis $\mathrm{H}_{1}: \mathrm{P}<10.02 \%$. To test this hypothesis, we use normal test statistic Z. Using the information based on the sample size 93 we get the value of $\mathrm{Z}$ as $\mathrm{Z}=2.52$ which is greater than 1.64 (standard normal table value at $5 \%$ level of significance). This implies death rate after Ayurvedic treatment is reduced significantly at $5 \%$ level of significance.

\section{DISCUSSION}

According to modern science of medicine, till date there is no any medicine on Covid-19 infection. According to Ayurveda texts, Covid-19 infection and spread can be correlated with Janapadodhvansa Vyadhi and Sansargajanya Vyadhi. In this infection, we have seen the complaints such as Fever, Cough, Cold, Breathlessness, Generalized Weakness, sore throat, Vomiting / Nausea and Loss of appetite. According to Ayurveda basic principles and as per our observation, in covid-19 infection, the complaints are developed due to Vaata and Kapha Dosha Prakopa. In this study, we have seen the two major symptoms, 85 i.e. $91.39 \%$ had history of fever; 89 i.e. $95.70 \%$ has history of Loss of appetite. Basic Samprapti (pathophysiology) development starts from these symptoms. Loss of appetite means Agnimandya and this is a main cause of Fever i.e. Jwara. Near about all subjects had history of these both symptoms and this shows the process of disease development was taken place in Rasaraktavahastrotasa (Circulatory System). Agnimandya generates Aama (Indigested food part) in Amashaya (Stomach) and this Aama get absorbed in Rasavahastotasa. After going in Rasavahastrotasa, Rasadhatvagni cannot digest the Aama due to Rasadhtvagnimandya and blockages was developed in Rasavahastrotasa which results in Jwara i.e. fever. Fever was suppressed to some extent due to taking of antipyretic modern medicines. But due to $R a$ sadhatvanimandya, Rasa Mala Kapha was generated in large quantity which is similar to the Aama. Raktadhatvagnimandya was also developed by this Mala Kapha and Aama. "Kupitanam Hi Doshanam, Sharire Pari Dhavatam | Yatra Sanga Khavaigunyat Vyadhistatropajayate ||"Su.Su.24/19. This sutra explains how the disease develops in the body. Kupit Dosha travels through Rasaraktavahastrotasa (we can say blood stream) and disease development takes place at the place according to the dominancy of the Dosha i.e. Sthansanshraya. In covid-19 infection lungs gets affected and main symptoms are related to lung infection which are Cough, Pneumonia. According to Ayurvedic texts, "Kaphasyasutaramuraha" i.e. Ura (Chest area) is the main place of Kapha Dosha. That's why in this infection we see the symptoms related to Kapha Dosha. And after Sthansanshraya subjects had developed other symptoms of cough, breathlessness.

"Uraha Sthanam Udanasyal" means Ura is also place of Udana Vayu. Due to development of pneumonia, 
Vaata Dosha also gets affected and Prana and Udana Vaayu Dushti take place. Udana Vayu has his main function to give and maintain Strength i.e. Bala to our body. But due to Avarodha and Dushti, Udana Vayu cannot give Bala to the body and Dourbalya i.e. Generalized weakness was seen in $88.17 \%$ i.e. 82 subjects. Utpatti and Poshana of Kantha i.e. throat is from Raktadhatu. As said earlier, Raktadhatvagimandya and Kapha Prakopa both pathological conditions have importance in symptom of Sore Throat. Due to this Samprapti $59.55 \%$ i.e. 53 subjects had developed sore throat complaint.

Nausea and vomiting complaint were seen in only $3.3 \%$ i.e. 3\% subjects. This was due to Agnimandya and generation of Aama in Stomach (Aamashaya) as discussed earlier.

To treat the symptoms of Cough, Loss of Appetite, Breathlessness, Sore Throat, Vomiting/Nausea, we had started a combination of medicines named 'Shwashara'. It was given along with allopathic medicines. From this kit, Combination of powder form of Tribhuvankirti Rasa, Tankanmarit Abhraka, Kalingakadi, Patoladi Guggulu, Chaturthaka was given to the Subjects at 6 am i.e. empty Stomach and After Both meals with warm water. Haralu was given at 10 am and 6 pm And Nagaradi Kalpa at 6 am i.e. empty Stomach and After Both meals.

From the contents of TribhuvankirtiRasa, Hingula is Kaphadoshahara, it reduces Kapha, Vatsanabha also Tejmahabhutpradhana, reduces Kapha and inflammation, swelling. Pippali and Pippalimula is Tejmahabhutpradhana, increases appetite, reduces Kapha. Tankana reduces Kapha, Tejmahabhutapradhana. Shunthi has Pachana, Grahi properties helps to decrease Kapha. Maricha is Tejmahabhutpradhana and has Pramathi property which helps to excrete the $\mathrm{Ma}$ la Bhaga from the body; it also helps to decrease Kapha from upper respiratory tract. Tulasi, Dhattura and Ardraka are Tejmahabhutpradhana, Jwaranasha$k a$, stimulate sweating and reduce swelling. Overall Tribhuvankirti Rasa is Tejmahabhutpradhana Kalpa and has important role in Upper respiratory tract infection especially when there is dominancy of Vaata and Kapha Doshas. By digesting Aama, it reduces the
Jwara (Fever). It is also useful in Lung infection and related symptoms.

"TankanmaritAbhraka" is Tejmahabhutpradhana Kalpa. It helps to reduce the Jwara (fever) increasing properties i.e. the Aama and it strengthen the lungs which is beneficial for every subject to recover earlier. "Kalingakadi" i.e. Rasapachaka is helpful to recover from Rasadhatu Dushti. It increases Rasadhatvagni, decreases Aama and Dushta Kapha. This helps to decrease the process of pneumonia development, decreases generalized weakness. By these properties it also decreases Cough.

"Patoladi Guggulu" i.e. Raktapachaka is helpful to recover from Raktadhatu Dushti. It increases Raktadhatvagni. As per texts, Lungs are nourished by Saara (fine) part of Raktadhatu. That's why it helps to strengthen the lungs.

Meda Dhatu is similar to Kapha Dosha, that's why "Chaturthaka" i.e. Medopachaka is helpful to reduce Kapha, pneumonia. By the use of these all Pachaka's Rasaraktasavvahana i.e. circulatory system remains undisturbed. These three Pachaka's can be helpful to reduce the further complications like Liver injury, Kidney injury, further blockages, lung fibrosis etc.

'Nagaradi Kalpa' helps as an expectorant. It promotes drainage of mucus from lungs by thinning the Kapha and it lubricates the respiratory tract because of Aapa Mahabhuta. This helps to prevent from lung damage, oxygen injury. It also helps to reduce the Jwara (fever).

This total combination of 'Swasahara' was given to 93 subjects. Among 93 subjects 90 i.e. $96.77 \%$ had cough; 83 i.e. $89.25 \%$ had Breathlessness; 82 i.e. $88.17 \%$ had Generalized weakness; 53 i.e. $59.55 \%$ had sore throat; 3 i.e. $3.3 \%$ had Vomiting/Nausea and 2 i.e. $2.2 \%$ had Loss of appetite. This shows that more Cough, Breathlessness, Generalized weakness and loss of appetite were the most common symptoms while treating patients.

All subjects had age more than 25 years. 12 i.e. $12.90 \%$ had age below 40 years; 44 i.e. $47.31 \%$ had age between 41 to 60 years and 37 i.e. $39.78 \%$ had age equal to or more than 61 years. This shows that subjects having age equal to and more than 41 were 
largely infected. Among 93 Subjects 63 i.e. 67.74\% were male and 30 i.e. 32.26 were female. This shows that Males were more prone to Covid-19 infection than Females.

71 i.e. $76.34 \%$ subjects had co-morbidities. Among these, 26 i.e. 36.61\% had Diabetes Mellitus (DM); 18 i.e. $25.35 \%$ had Hypertension (HTN); 22 i.e. $30.99 \%$ had both DM and HTN; 5 i.e. 7.04\% had other comorbidities like Parkinson's disease, Asthma, Angioplasty etc. And in total, 22 i.e. $23.66 \%$ subjects had no co-morbidity. This shows that among all comorbidities DM and HTN were the most common.

Medicines were started to $40.86 \%$ i.e. 38 subjects when they were on Oxygen support of equal to or more than $6 \mathrm{lpm}$. Medicines were started to $31.18 \%$ i.e. 29 subjects when they were on Oxygen support of 0-5 lpm. Medicines were started to $27.96 \%$ i.e. 26 subjects when they were not on Oxygen support. This data shows that 67 i.e. $72.04 \%$ had needed oxygen support during treatment. Out of these 67 subjects, $25.37 \%$ i.e. 17 had needed oxygen support for 1 to 3 days; $50.74 \%$ i.e. 34 had needed oxygen support for 4 to 7 days; $16.41 \%$ i.e. 11 had needed oxygen support for 8 to 10 days; $7.46 \%$ i.e. 5 had needed oxygen support for more than 10 days. This data shows that, 51 subjects had needed oxygen support equal to or less than 7 days. $58.26 \%$ i.e. 54 subjects were recovered within 7 days. $32.25 \%$ i.e. 30 were recovered within 8 to 10 days and $9.67 \%$ i.e. 9 were recovered after 11 days. This data shows that, $58.26 \%$ subjects were recovered within seven days. Along with modern medicines Ayurvedic medicines were useful to reduce the external oxygen demand by decreasing pneumonia and cough.

$27.96 \%$ i.e. 26 subjects did not need oxygen support during treatment. And out of these 26 subjects 21 i.e. $80 \%$ subjects were having co-morbidities. This data shows that, our medicines were useful to strengthen the lungs; subjects were prevented from increasing complaints even in co-morbidities which were more prone to increase the symptoms.

HRCT investigation had been done by 68 i.e. $73.12 \%$ subjects. Out of these, 49 i.e. $72.05 \%$ had score above $50 \%$ and out of these, 13 i.e. $26.53 \%$ did not require oxygen support during treatment. This data shows that, we were given very good results even the HRCT score was more than $50 \%$.

Out of 93 subjects 2 i.e. $2.15 \%$ death has been recorded. Out of these two deaths, one death was due to myocardial infarction but not due to pneumonia. Death was happened when the subject was getting recovered. And second death was due to noncooperation of subject during oxygen support.

This total data shows that along with modern medicines, 'Shwashara' medicines have very good results. In Vivekanand Hospital, total 471 subjects were admitted for covid-19 treatment and treated with modern medicines. Out of these, 47 deaths were recorded. This shows hospital has $10.02 \%$ death rate. And out of these 471 subjects 93 subjects were treated with both modern and Ayurvedic medicines. And this study shows the death rate $2.15 \%$ and this is very less than hospital death rate. By the use of 'Shwashara' medicines along with modern medicines the death rate was reduced significantly.

\section{CONCLUSION}

From this study we can conclude that, while treating Covid-19/SARS-Cov-2 infection, along with modern treatment, 'Shwashara' Ayurvedic medicines have very good results in all age factors, co-morbidities, high quantity requirement of oxygen, high HRCT score. Medicines are also useful in initial stage to prevent subjects from increasing symptoms and recover earlier. And the most important in Covid-19 infection is that this treatment is very helpful in subjects having co-morbidities and to reduce the death rate. The treatment is also useful to decrease the process of pneumonia development, strengthen lungs, reduces chances of oxygen injury and can be useful to prevent formation of lung fibrosis. That's why we can say that 'Shwashara' medicine is beneficial in every stage of Covid-19 infection.

\section{REFERENCES}

1. https://science.wire.in/health/india-covid-19-mortalitycomorbidities-age-health-ministry/ -14/10/2020 
2. Charak Samhita, Charak-Chandrika Hindi Vyakhyaya, Vyakhyakaar Dr Brahmanad Tripathi, Edited By Dr. Gangasahay Pandey, Caukhamba Surabharati Prakashan, Varanasi, Printed 2003, Vimansthana, Chapter 3, Page 675.

3. Vanaspatinche Swabhav Arthat Gunadharmashastra Vaidyaraj Atmaram Vaman Datar - Third Edition 2007, Vaidyaraj Datar Panchabhautik Chikitsa Va Sanshodhan Kendra, Sangli, Page 75.

4. Vanaspatinche Swabhav Arthat Gunadharmashastra Vaidyaraj Atmaram Vaman Datar - Third Edition 2007, Vaidyaraj Datar Panchabhautik Chikitsa Va Sanshodhan Kendra, Sangli, Page 95.

5. Brihat-Trayeeratna Vaidyaraj A.V. Datar Pranit Panchabhautik Chikitsa Paddhatimadhil Vees Pramukh Aushadhi Kalpa, Dr. Sudhakar Haladavanekar, Second Edition 2006, Chaturthak, Page 72.

6. Vaidyaraj A.V. Datar Pranit Panchabhautik Chikitsapaddhatimadhil Vees Pramukh Aushadhi Kalpa (Bhag 2 -Vd. Aniruddha Shridhar Kulkarni And Vd. Sou. Amruta Padmanabh Joshi, First Edition 2013, Vaidyaraj Datar Panchabhautik Chikitsa Va Sanshodhan Kendra, Sangli, Page 52.

7. Brihat-Trayeeratna Vaidyaraj A.V. Datar Pranit Panchabhautik Chikitsa Paddhatimadhil Vees Pramukh Aushadhi Kalpa, Dr. Sudhakar Haladavanekar, Second Edition 2006, Chaturthak, Page 71.

8. Brihat-Trayeeratna Vaidyaraj A.V. Datar Pranit Panchabhautik Chikitsa Paddhatimadhil Vees Pramukh Aushadhi Kalpa, Dr. Sudhakar Haladavanekar, Second Edition 2006, Chaturthak, Page 43.

9. Vanaspatinche Swabhav Arthat Gunadharmashastra Vaidyaraj Atmaram Vaman Datar - Third Edition 2007, Vaidyaraj Datar Panchabhautik Chikitsa Va Sanshodhan Kendra, Sangli, Page 121.

10. Ayurvediya Aushadhi Gunadharmashastra, Part 1 To 5 - Vaidyapanchanan Gangadharshastri Gopalrao Gune, Reprint 2005, Sou. L. P. Vaidya, Page No.348

\section{Source of Support: Nil Conflict of Interest: None Declared}

How to cite this URL: Ravindrakumar Mane \& Ram Lade: To Study the Efficacy of Ayurvedic Treatment in Covid-19/SarsCov-2. International Ayurvedic Medical Journal \{online\} 2021 \{cited January, 2021\} Available from: http://www.iamj.in/posts/images/upload/2680_2688.pdf 